\title{
Prospects of Phytoremediation and Phytoindication of Oil-Contaminated Soils with the Help of Energy Plants
}

\author{
Nataliia Igorivna Glibovytska ${ }^{1 *}$, Krystyna Bogdanivna Karavanovych, \\ Taras Bogdanovych Kachala' \\ 1 Institute of Natural Sciences and Tourism, Ivano-Frankivsk National Technical University of Oil and Gas, \\ 15 Carpathian Street, 76000, Ivano-Frankivsk, Ukraine \\ * Corresponding autor's e-mail: nataly.glibovytska@gmail.com
}

\begin{abstract}
An analysis of energy plants from the point of view of their suitability for remediation of oil-contaminated territories was carried out. Plantations of Salix viminalis L., Helianthus tuberosus L. and Medicago sativa L. were planted with the purpose of remediation of the territory where active oil production is conducted. The prospect of using Salix viminalis and Helianthus tuberosus as effective restorers of technogenically-transformed environment quality was revealed. The limiting factors restricting the growth of Salix viminalis on degraded soils were established, involving dry air and insufficient soil moisture. Medicago sativa is sensitive to the level of soil contamination by pollutants and can act as a phytoindicator of the environmental quality of oil-contaminated ecosystems.
\end{abstract}

Keywords: energy plants, oil pollution, phytoremediation, phytoindication, soil.

\section{INTRODUCTION}

Because of the problem of environmental oil pollution resulting from oil extraction, transportation and processing, there is a need for purification and restoration of the functional state of all ecosystem components. Soil is the ultimate depositing environment for all pollutants entering the surrounding space. Therefore, the issue of soil remediation contaminated by oil is one of the main environmental problems of the present days. Previous studies [Glibovytska, Karavanovych, 2018] have established the prospect of using certain trees to restore degraded soils.

The purpose of this work is to analyze and study the suitability of so-called energy plants for the phytoremediation of oil-contaminated areas.

Numerous energy crops are used around the Word, including: Salix viminalis L., Populus alba L., Populus nigra L., Reynoutria sachalinensis (F.Schmidt) Nakai, Phalaris arundinacea L., Panicum virgatum L., Populus tremula L., Rosa multiflora L., Sida hermaphrodita (L.) Rusby., Helianthus tuberosus L. Energy willow (Salix viminalis L.) is the most popular energy crop in Ukraine [Gumniecik, 2013; Geltukha et al., 2014]. We are also interested in the Helianthus tuberosus L, so-called Jerusalem artichoke, known for its exceptional characteristics, including the capability to grow on virtually all substrates, even contaminated by household rubbish and heavy metals. We also paid attention to Medicago sativa L., so called alfalfa, the grass plant that is widespread throughout Ukraine and which serves as a valuable and nutritious fodder crop.

\section{MATERIALS AND METHODS}

The research was carried out within the actively operating Bytkov-Babchensky oil deposit located in the Nadvirna district of the IvanoFrankivsk region. Previous studies [Kachala 2014; 2016] found that in the experimental section, maximum levels of soil contamination by oil were observed, which defined the choice of territory for research. 
The planting of alfalfa and artichoke seeds and seedlings of energy willow in the soil was carried out early in the spring, immediately after frosts. At this time, the humidity of the soil is the highest. Transplantation of seedlings in the soil was carried out manually. The $33 \mathrm{~cm}$ x $70 \mathrm{~cm}$ plots were sprinkled in advance and cleared of weeds. The width of each section is $4.0 \mathrm{~m}$; length $-7 \mathrm{~m}$; area $-28 \mathrm{~m}^{2}$. Seedlings of energy willow were planted in such a way that a part of the plant remained above the level of the ground.

The observations were carried out once every ten days in order to fix the growth and development of plants.

\section{RESULTS AND DISCUSSION}

Energy willow is characterized by rapid growth and biomass accumulation, it is used as a biofuel and environmental phytomeliorant. This species effectively absorbs carbon dioxide, produces oxygen due to the large contact area of photosynthetic organs with the environment [Gumetnik, 2013]. The energy willow is susceptible to the presence of weeds and pests. The cultivation experience of this species is available in some European countries, in particular Denmark, Sweden, Poland, England, Austria, Hungary, Romania, Serbia. In Ukraine, plantations of energy willow are located in IvanoFrankivsk, Volyn, Lviv, Ternopil and Rivne regions [Royik et al., 2013]. The vitality of planting material is no less than $85 \%$. The growth of willow seedlings in the first year after planting is highly dependent on the weather conditions. The harvest can be carried out only for the fourth year after laying the plantation [Denisyuk et al., 2016].

Another benefit of energy willow is that about $60-80 \%$ of nutrients return to the soil along with the fallen leaves [Geltukha et al., 2014]. Salix viminalis plantations prevent soil erosion, promote the quality of the environment, enrich the soil with mineral and trace elements [Royik et al., 2013]. The energy willow is ideally suited for planting the contaminated and unproductive land, used as buffer zones in places where biological waste from farms is accumulated, for the remediation of urban sewage sludge. The plantation of energy willow is a natural filter for the removal of agricultural production waste, the purification of soils from pesticides, phosphorous and nitrate fertilizers [Gumentik, 2013]. The energy willow removes some heavy metals from the ground, positively affects the enrichment of soil with carbon dioxide and bacteria that increase fertility [Hultgren, Pizzul, 2009].

According to some authors [Stalsa et al., 2010; Jassen, 2015], the species belongs to heavy metals eliminators and with the growth and development of this plants, the biological availability of metals is reduced. Other publications [Zimmera, 2011; Yergeau et al., 2014] indicate that the energy willow has a unique ability to absorb, deactivate and accumulate large amounts of heavy metals without reducing the growth processes. Compared with other energy plants, willow accumulates more metals in terms of dry mass. Heavy metals are localized in different parts of the plant. In particular, lead, chromium and copper predominantly accumulate in the above-ground part, since they have greater mobility. The leaves of the species are most likely to accumulate zinc, chromium, lead, arsenic, steel, while the roots accumulate molybdenum, copper, nickel, zirconium, barium and iron [Zimmera et al., 2011; Sylvaina et al., 2016; Francois et al., 2017].

With the growth on heavily contaminated territories, Salix viminalas exhibits high tolerance to metals, since accumulation of metals in underground organs under extreme growth conditions is much more intense than in slightly polluted soils [Cristaldi et al., 2017]. This adaptive ability to block the movement of critical concentrations of metals in the above-ground organs allows the plant to develop normally under extreme stress conditions. In addition, the accumulation of metals is much more intense in the lower parts of the above-ground organs than those located higher. These protection mechanisms confirm the high resistance of the species to the toxic effects of pollutants.

The biological diversity of flora and fauna around the Salix viminalis plantations is improved [Gumentik, 2013]. The energy willow belongs to the highly transpirational plants and grows well on wetlands; this property is used to drain these muds. It is known that energy willow can grow on different types of soils, marshy and unproductive lands, reclaimed open-mined land, contributing to the formation of humus [Ruttens et al., 2011; Lebrun et al., 2017].

Resistance to frost, pests and diseases constitute a very important feature of Salix viminalis [Royik et al., 2013]. Of course, in low-quality lands, Salix viminalis does not grow as quickly as under favorable conditions, but a well-developed 
root system helps to maintain the intensive plant's growth [Denisyuk et al., 2016].

The combustion heat of Salix viminalis dry wood is equal to the combustion heat of softwood species (18.5 mJ / kg), which provides energy independence and an alternative to natural gas [Kurhak et al., 2013]. In addition, the species can be burned without further refinement and predrying, which saves resources. There is as much carbon dioxide entering the atmosphere during the combustion as absorbed in the process of photosynthesis during the growth period. The heat capacity of herbaceous plants is lower compared to woody plants. Herbs contain many alkaline elements and have high ash content. Thus, woody plants and shrubs have a significant energy advantage over grassy plants. The sufficient amount of precipitation and a high level of groundwater are the required conditions for Salix viminalis growth. The optimum plant growth is maintained on slightly acidic soils with a $\mathrm{pH}$ of 5.5-6.5, but can also occur on soils with a $\mathrm{pH}$ varying from 3.5 to 10 [Royik et al., 2013].

The rapid growth of energy willow is one of the most important criteria of the species suitability for the remediation of oil-contaminated areas. However, the question of the effectiveness of restoring oil-contaminated soil using energy willow is still not well understood. According to some authors [Mittonab et al., 2012; Weyens et al., 2013; Musilova et al., 2016; Yergeau et al., 2018], the energy willow can significantly accelerate the development and reproduction of microorganisms that detoxify the chlorinated and aromatic hydrocarbons present in oil and petroleum products. This is due to the activation of microorganisms genes by so-called secondary plant metabolites, terpenes and phenolic molecules. In addition, symbiotic bacteria can stimulate the flow of toxicants available in oil to the root of plants. The next step is accumulation of toxicants in plant organs, their transformation into simple and harmless compounds or detoxification to gaseous substances that are secreted by the plant in the process of gas exchange. The microorganisms that participate in symbiotic relationships with species of the Salix genus belong to the following orders: Actinomycetales, Rhodospirillales, Burkholderiales, Alteromonadales, Solirubrobacterales, Caulobacterales, and Rhizobiales. Other authors [Kidd et al., 2015; Lim et al., 2016; Tozser et al., 2017] confirm that the purification of contaminated areas from petroleum products requires a longer period with the use of energy willow, since the absorption of hydrophobic oil components by the cells of the plant root is very slow.

The studies conducted by the authors (Fig. 1) showed that the willow seedlings grew well on oil-contaminated soils in the Bytkov-Babchensky oil deposit (Fig. 2).

During their planting it rained heavily and the soils of the experimental territory were strongly moistened. In our opinion, this has caused the growth of $99 \%$ of the species seedlings on the oil deposit. However, high air temperatures and uncommon rains in the summer of 2018 became

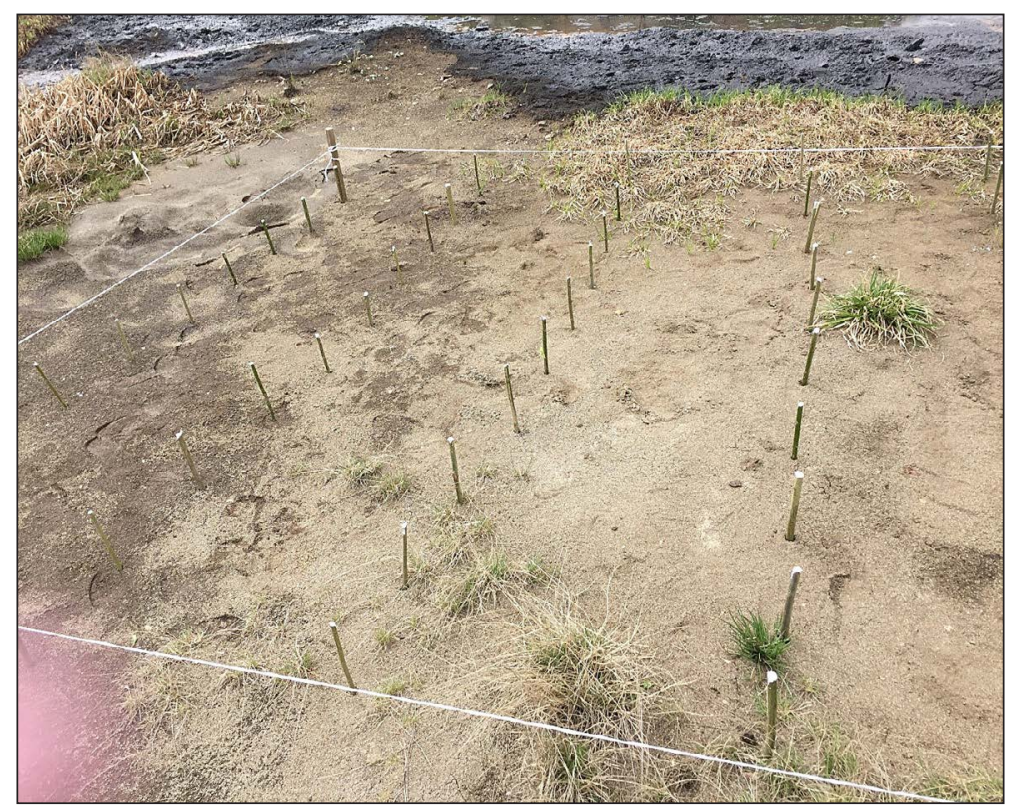

Fig. 1. Plantation of Salix viminalis L. under conditions of oil and gas deposit 


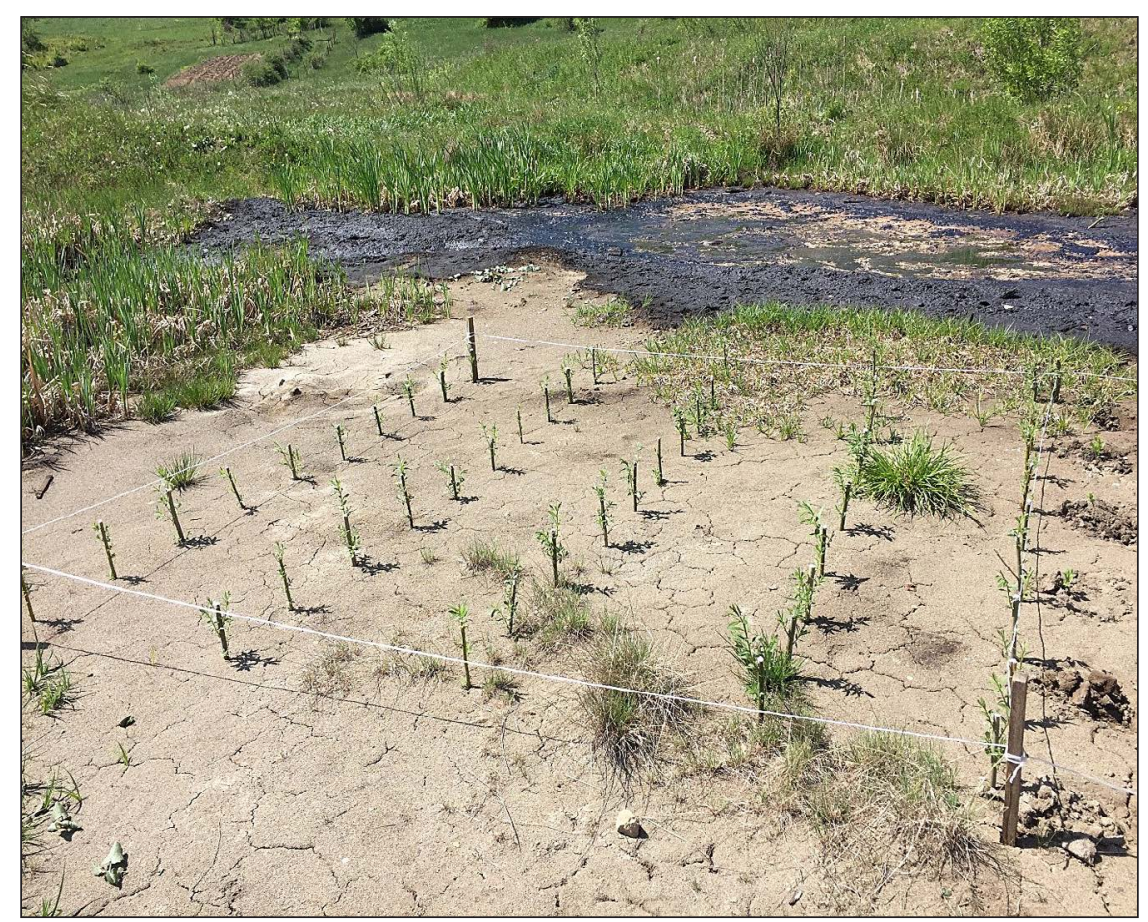

Fig. 2. Germinated Salix viminalis plants under conditions of oil and gas deposit (May 2018)

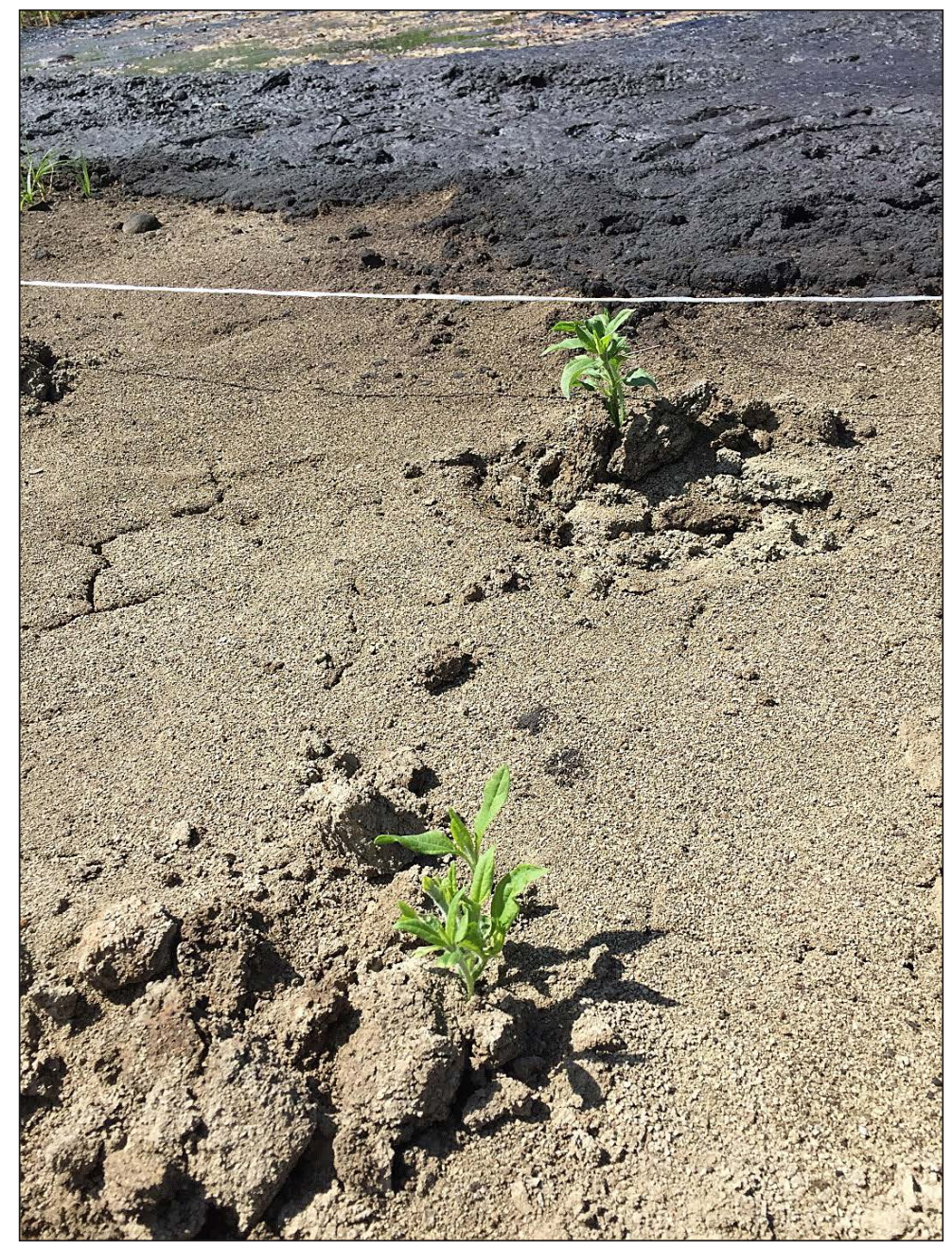

Fig. 3. Germinated Medicago sativa individuals under conditions of an oil deposit (May 2018) 
an obstacle to the full development of willow seedlings and led to the drying of plants at the juvenile stage of development. Thus, the weather conditions have become the limiting factors for the growth of Salix viminalis on oil-polluted soil. For full-fledged development of plants, it is necessary to carry out additional irrigation of plantations during the arid period of the year.

Alfalfa (Medicago sativa L.) is a representative of the Fabaceae family, which is widespread in Ukraine. Medicago sativa has a well-developed root system, enriches the soil with nitrogen as well as creates favorable conditions for the development of microorganisms-destroyers of oil and petroleum products in its rhizosphere [Liu, 2012; Shevchyk, Romanyuk, 2017]. According to literature data [Minoui, 2015; Xiao et al., 2015; Panchenko et al., 2017], this species is capable of tolerating low concentrations of oil and accelerate the decomposition of its toxic components by rapidly developing of microorganisms-symbionts.
However, medium and especially high concentrations of petroleum products in soils inhibit the growth and development of alfalfa, as well as cause necrotic lesions of assimilation organs [Chekol, Vough, 2001; Gouda et al., 2016].

Under oil-polluted environment conditions, only $20 \%$ of the alfalfa seedlings showed vitality, while the rest died and did not sprout (Fig. 3).

The results of our studies showed that the cultivation of Medicago sativa on heavily contaminated petroleum soils negatively affects the plant, promoting growth and development retardation. This, in turn, is a sign of the exhaustion of the body's protective forces under stressful conditions of growth and is a bioindicative characteristic of the species. According to some authors [Marchand et al., 2016; Jahantab et al., 2018], the introduction of organic compost significantly improves the absorption efficiency of pollutants present in oil, as well as stimulates the

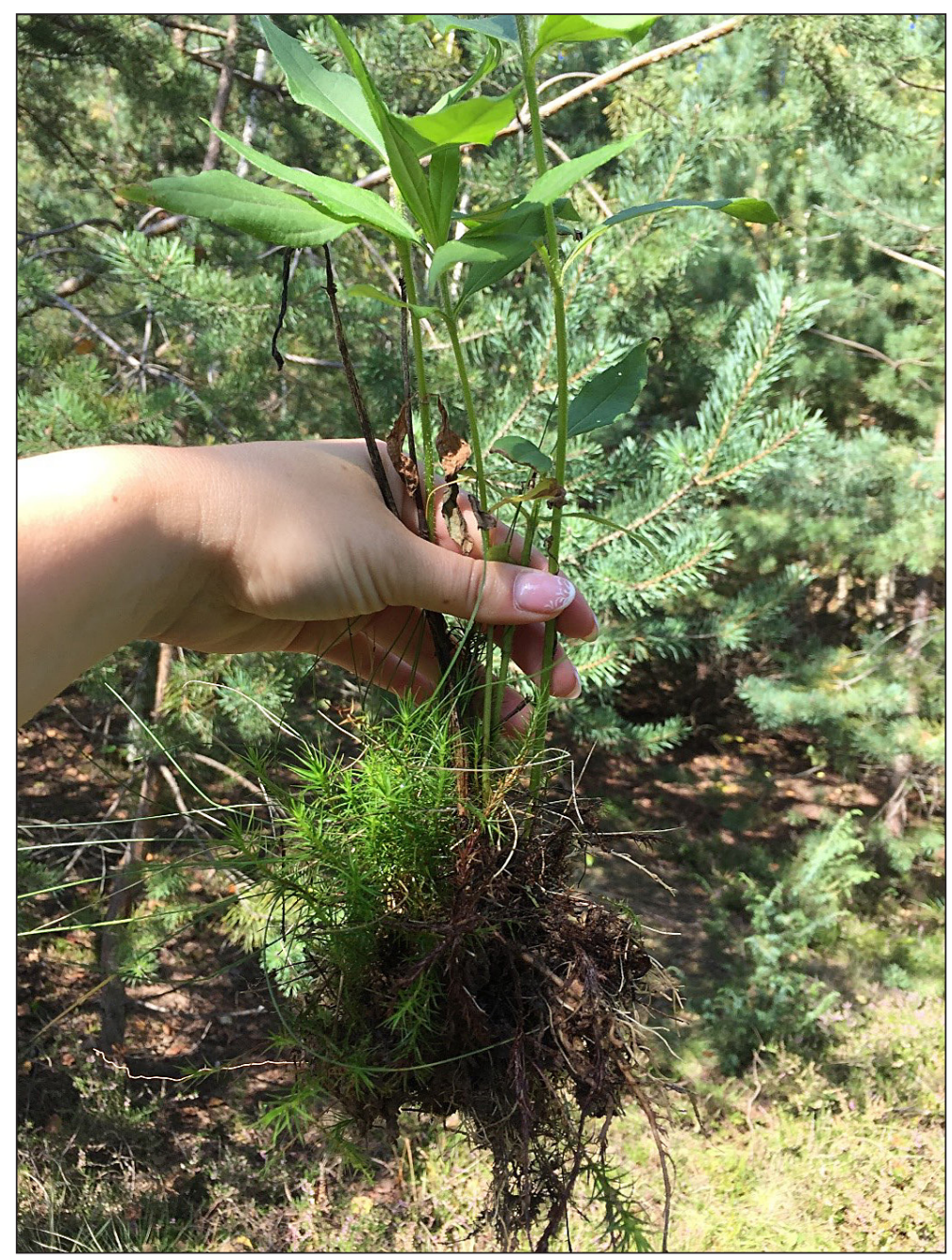

Fig. 4. Helianthus tuberosus individuals under conditions of oil and gas deposit (May 2018) 
development of symbionts, and even the appearance of earthworms in the ground.

Jerusalem artichoke (Helianthus tuberosus L.) constitutes one of the leading bioenergetic crops used as a technical, food plant and a raw material for the production of ethanol, as well as an effective phytomeliorant of the environment. Helianthus tuberosus is characterized by high frost resistence, can withstand short-term droughts, because it absorbs moisture from deep soil layers [Tsvetkov, Doncheva, 2015]. Drought-tolerance contributed to the fact that seedlings of the artichoke successfully sprouted and acclimated under the influence of the oil deposit.

Helianthus tuberosus is capable of creating competition and completely squeezing out weeds, including dwarf Sosnovsky [Geltukha et al., 2014]. The species grows even on landfills and low-yielding soils. Jerusalem artichoke forms twice as large leaf area as a 50-year-old hardwood forest, enriches air with oxygen, absorbs nitrates and heavy metals from the soil and is used in the fight against radionuclides [Feshchenko, 2012; Li, 2018]. The green mass of Jerusalem artichokes absorbs twice as much carbon dioxide from the atmosphere as a hectare of forest [Long, 2012]. Harmful substances are concentrated in the green mass, whereas they do not accumulate in the root itself [Geletuha et al., 2013]. All of the above-mentioned unique properties of the plant serve as a basis to consider the species suitable for the restoration of technogenically-transformed environment.

Our research found that Helianthus tuberosus grows well on oil-contaminated soil (Fig. 4).

Under the influence of the Bytkov-Babchensky deposit, a good development of the individuals of the species is observed, which manifests itself in the intensive growth of vegetative organs, both photosynthetic and underground.

\section{CONCLUSIONS}

Our research found that energy willow and Jerusalem artichoke grow well on a highly contaminated soil, which gives reasons for recommending these species for phytoremediation of oil-contaminated territories. Alfalfa is not recommended for remediation of oil-contaminated areas, because the species is sensitive to severe pollution and is not adapted to long-term exposure to high concentrations of petroleum products. It is expedient to use alfalfa as a phytoindicator of oil productive territories in order to control the state and possible changes in the ecological situation of the environment in these territories.

\section{REFERENCES}

1. Chekol T.,Vough L. 2001. A Study of the Use of Alfalfa (Medicago sativa L.) for the Phytoremediation of Organic Contaminants in Soil. Remediation Journal banner, 11(4), 89-101.

2. Courchesne F., Turmel M., Cloutier-Hurteau B., Constantineau S., Munro L., Labrecque M. 2017. Phytoextraction of soil trace elements by willow during a phytoremediation trial in Southern Québec, Canada. International Journal of Phytoremediation, 19 (6) 545-554. https://doi.org/10.1080/1 5226514.2016.1267700

3. Cristaldi A., ContiG., Eun HeaJho E., Zuccarello P., Grasso A., Copat C., Ferrante M. 2017. Phytoremediation of contaminated soils by heavy metals and PAHs. A brief review. Environmental Technology \& Innovation, 8, 309-326. https://doi. org/10.1016/j.eti.2017.08.002

4. Denisyuk S.P., Kotsar O.V., Chernetskaya Yu.V. 2016. Energy efficiency of Ukraine. Best project ideas: Project «Professionalization and stabilization of energy management in Ukraine». K.: KPI them. I. Sikorsky, 79.

5. Feshchenko V.P. 2012. Ways of minimizing the radioecological burden on the population of Zhytomyr region. Ecological safety. Bulletin of the Mikhail Ostrogradsky Str., 4 (75), 160-164.

6. Geletukha G.G., Zhelezna T.A., Tryboy O.V. 2014. Prospects for growing and using energy crops in Ukraine. Analytical note BAU № 10 Bioenergetic Association of Ukraine, $33 \mathrm{p}$.

7. Geletukha G.G., Zhelezna T.A., Oliynyk E.N. 2013. Prospects for the production of thermal energy from biomass in Ukraine. Industrial Heat Engineering, 35 (4), 5-15.

8. Glibovytska N.I., Karavanovych K.B. (2018). Morphological and physiological parameters of woody plants under conditions of environmental oil pollution. Ukrainian Journal of Ecology, 8(3), 322-327.

9. Gomenik M.Ya. 2013. Atlas of high-yielding bioenergy crops. Bioenergetics, 2, 6-7.

10. Gouda A., El-Gendy A., Abd El-Razek T., El-Kassa H. 2016. Evaluation of Phytoremediation and Bioremediation for Sandy Soil Contaminated with Petroleum Hydrocarbons. International Journal of Environmental Science and Development, 7(7), 490-493.

11. Jahantab E., Jafari M., Motasharezadeh B., Ali T. 2018. Remediation of Petroleum-Contaminat- 
ed Soils using Stipagrostis plumosa, Calotropis procera L., and Medicago sativa ünder Different Organic Amendment Treatments. 6, (2), 101-109.

12. Janssen J., Weyens N., Croe S., Beckers B., Meiresonn L., Van Peteghem P., Carlee R., Vangronsvel J. 2015. Phytoremediation of Metal Contaminated Soil Using Willow: Exploiting Plant-Associated Bacteria to Improve Biomass Production and Metal Uptake. International Journal of Phytoremediation, 17 (11), 1123-1136, DOI: 10.1080/15226514.2015.1045129

13. Hultgren J., Pizzul L. 2009. Degradation of PAH in a Creosote-Contaminated Soil. A Comparison Between the Effects of Willows (Salix Viminalis), Wheat Straw and A Nonionic Surfactant. International Journal of Phytoremediation, 12(1), 54-66. https://doi.org/10.1080/15226510902767122

14. Kachala T.B. 2014. Investigation of oil-contaminated land plots in Ivano-Frankivsk region. Ecological safety and balanced resource use, scientific and technical journal, Ivano-Frankivsk. Special Issue. 4-9.

15. Kachala T.B. 2016. Monitoring of the soil cover of exhausted oil and gas deposits. Ecological safety and balanced resource use, scientific and technical journal, Ivano-Frankivsk. 2. 40-44.

16. Kidd P., Mench M., Álvarez-López V., Bert V., Dimitriou I., Friesl-Hanl W., Herzig R., Janssen J., Kolbas A., Mülle I., Ne S., Renella G., Ruttens A., Vangronsveld J., Puschenreiter M. 2015. Agronomic Practices for Improving Gentle Remediation of Trace Element-Contaminated Soils. International Journal of Phytoremediation. 17 (11), 1005-1037. https://doi.org/10.1080/15226514.2014.1003788

17. Kurgan V.G. 2013. Bioenergy potential of perennial herbaceous phytocoenoses. Collection of scientific works of the Institute of Bioenergetic Cultures, 19, 63-68.

18. Mittonab F., Gonzalezab M., Peñac A., Miglioranzaab K.. 2012. Effects of amendments on soil availability and phytoremediation potential of aged p,p'-DDT, p,p'-DDE and p,p'-DDD residues by willow plants (Salix sp.). Journal of Hazardous Materials, 203-204, 62-68. https://doi.org/10.1016/j. jhazmat.2011.11.080

19. Stalsa M., Carleera R., Reggersa G., Schreursb S., Ypermana J. 2010. Flash pyrolysis of heavy metal contaminated hardwoods from phytoremediation: Characterisation of biomass, pyrolysis oil and char/ash fraction. Journal of Analytical and Applied Pyrolysis, 89 (1), 22-29. https://doi.org/10.1016/j.jaap.2010.05.001

20. Yergeau E., Sanschagrin S., Maynard C., St-Arnaud M., Greer C. 2014. Microbial expression profiles in the rhizosphere of willows depend on soil contamination. The ISME Journal, 8, 344-358.
21. Zimmera D., Krusea J., Bauma C., Borcab C., Lauec M., Haused G., Meissnere R., Leinwebera P. 2011. Spatial distribution of arsenic and heavy metals in willow roots from a contaminated floodplain soil measured by X-ray fluorescence spectroscopy. Science of The Total Environment. 409 (19), 4094-4100. https://doi.org/10.1016/j.scitotenv.2011.06.038

22. RuttensA., Boulet J., Weyens N., Smeets K., Adriaensen K., Meers E. 2011. Short Rotation Coppice Culture of Willows and Poplars as Energy Crops on Metal Contaminated Agricultural Soils. International Journal of Phytoremediation. 13, 194-207. https://doi.org/10.1080/15226514.2011.568543

23. Weyens N. 2013. Potential of willow and its genetically engineered associated bacteria to remediate mixed $\mathrm{Cd}$ and toluene contamination. Journal of Soils and Sediments, 13 (1), 176-188.

24. Sylvaina B., Mikael M., Florie M., Emmanuel J., Marilyne S., Sylvain B., Domenico M. 2016. Phytostabilization of $\mathrm{As}, \mathrm{Sb}$ and $\mathrm{Pb}$ by two willow species (S. viminalis and S. purpurea) on former mine technosols. CATENA, 136, 44-52. https:// doi.org/10.1016/j.catena.2015.07.008

25. TőzsérD., Magura T., Simon E.. 2017. Heavy metal uptake by plant parts of willow species: A meta-analysis. Journal of Hazardous Materials. 336, 101-109. https://doi.org/10.1016/j. jhazmat.2017.03.068

26. Lebrun M., Macri C., Miard F., Hattab-Hambli N., Motelica-Hein M., Domenico Morabito, Bourgerie S. 2017. Effect of biochar amendments on As and $\mathrm{Pb}$ mobility and phytoavailability in contaminated mine technosols phytoremediated by Salix. Journal of Geochemical Exploration, 182, B, 149-156. https://doi.org/10.1016/j.gexplo.2016.11.016

27. Marchand C., Hogland W., Kaczala F., Jani Y., Marchand L., Augustsson A., Hijri M. 2016. Effect of Medicago sativa L. and compost on organic and inorganic pollutant removal from a mixed contaminated soil and risk assessment using ecotoxicological tests. International Journal of Phytoremediation. 18(11), 1136-1147. https://doi.org/10.1080/1 5226514.2016.1186594

28. Minoui S., Shahriari M., Minai D. 2015. Phytoremediation of Crude Oil-Contaminated Soil by Medicago sativa (Alfalfa) and the Effect of Oil on its Growth. Phytoremediation for Green Energy, 123-129. DOI: 10.1007/978-94-007-7887-0_8

29. Musilova L., Ridl J., Polivkova M., Macek T., Uhlik O. 2016. Effects of Secondary Plant Metabolites on Microbial Populations: Changes in Community Structure and Metabolic Activity in Contaminated Environments. Int. J. Mol. Sci., 17(8), 1205. https://doi.org/10.3390/ijms17081205

30. Lim M.W., Lau E.V., Poh P.E. 2016. A comprehen- 
sive guide of remediation technologies for oil contaminated soil - Present works and future directions. Marine Pollution Bulletin, 109 (1), 14-45. https://doi.org/10.1016/j.marpolbul.2016.04.023

31. Li J., Zhang D., Zhou P., Liu Q. 2018. Assessment of Heavy Metal Pollution in Soil and Its Bioaccumulation by Dominant Plants in a Lead-Zinc Mining Area, Nanjing. Huan Jing Ke Xue. 39(8), 3845-3853. doi: 10.13227/j.hjkx.201712086.

32. Liu R., Jadeja R., Zhou Q., Liu Z. 2012. Treatment and Remediation of Petroleum-Contaminated Soils Using Selective Ornamental Plants. Environmental Engineering Science, 29(6), 494-501. doi:10.1089/ ees.2010.0490

33. Long X., Ni N., Wang L., Wang X., Wang J., Zhang Z., Zed R., Liu Z., Shao H. 2012. Phytoremediation of Cadmium-Contaminated Soil by Two Jerusalem Artichoke (Helianthus tuberosus L.) Genotypes. Xiaohua Long, 41(2), 202-209. https://doi. org/10.1002/clen.201100668

34. Panchenko L., Turkovskaya O., Muratova A. 2017. Comparison of the phytoremediation potentials of Medicago falcata L. And Medicago sativa L. in aged oil-sludge-contaminated soil. Environmental Science and Pollution Research 24, 3117-3130.
DOI: 10.1007/s11356-016-8025-y

35. Royik MV, Gomenik M.Ya., Mamysur V.V. 2013. Prospects for growing energy willow for the production of solid biofuels. Bioenergetics, 2, 18-19.

36. Shevchyk L.Z., Romanyuk O.I. 2017. Analysis of biological methods of recovery of oil-contaminated soils. Scientific Journal ScienceRise: Biological Science, No. 1 (4), 31-39.

37. Tsvetkov S., Doncheva S. 2015. Molecular responses of plants to environmental heavy metal contamination: lead and the use of sunflower in phytoremediation. Genetics and Plant Physiology, Volume 5(3-4), 201-230.

38. Xiao N., Liu R., Jin C., Dai Y. 2015. Efficiency of five ornamental plant species in the phytoremediation of polycyclic aromatic hydrocarbon (PAH)-contaminated soil. Ecological Engineering, 75, 384-391. https://doi.org/10.1016/j.ecoleng.2014.12.008

39. Yergeau E., Tremblay J., Joly S., Labrecque 3., Maynard C., Pitre F., St-Arnaud 3., Greer C. 2018. Soil contamination alters the willow root and rhizosphere metatranscriptome and the root-rhizosphere interactome. The ISME Journalvolume, 12, 869-884. 